\title{
Antibacterial activity of two Streptomyces species isolated from Egyptian and Libyan soils
}

\author{
Ahmed K.A. El-Sayed ${ }^{1 *}$, Mohamed I. Abou-Dobara ${ }^{1}$, Nouria S. El-Manafi ${ }^{2}$ \\ ${ }^{1}$ Botany Department, Faculty of Science, Damietta University, New Damietta, Egypt \\ ${ }^{2}$ Botany Department, Faculty of Science, Omer Al-Mokhtar University, Tobruk, Libya
}

Received: 24 May 2015 / Accepted: 2 September 2015

* Corresponding author: akaelsayed@du.edu.eg

\begin{abstract}
Sixty five actinomycetes isolates were collected from different Egyptian and Libyan soils. Forty eight isolates from the collected actinomycetes were found to be active against some tested pathogenic bacteria. Two different actinomycetes isolates (one from each country) which showed considerable higher antibacterial activity were identified as Streptomyces pluricolorescens and Streptomyces alni. They were also selected for optimizing the best conditions for their antibacterial activity production. The optimum incubation period, temperature and initial $\mathrm{pH}$ of medium for the maximum antibacterial yield were 5 days, $30^{\circ} \mathrm{C}$ and $\mathrm{pH} 7$, respectively, for both of Streptomyces species. The maximum antibacterial production was observed on Dox and starch ammonium sulfate media for S. pluricolorescens, while starch nitrate was the most suitable media for S. alni antibacterial productivity.
\end{abstract}

Keywords: Streptomyces, antibacterial activity, optimization.

\section{Introduction}

Actinomycetes are Gram-positive, free-living, saprophytic bacteria, widely distributed in soil, water, and colonizing plants. They form a distinct group of microbes as a class of their own. Early interest in actinomycetes focused mainly on their ability to yield antibiotics, along with certain vitamins and enzymes. Since the discovery of Actinomycin in 1940, the interest in the antibiotics produced by actinomycetes has been increased (Cassell and Mekalanos, 2001). From the 22,500 biologically active compounds that have been obtained from microbes, $45 \%$ are produced by actinomycetes (Bérdy, 2005). Many familiar bioactive compounds produced by actinomycetes possessed antibacterial (streptomycin, chloramphenicol, neomycin, novobiocin, nystatin, the tetracyclines, the erythromycins), antifungal (nystatin), antiviral (tunicamycin), antiparasitic (avermectin), immunosuppressive (rapamycin), antitumor (actinomycin, anthracyclines), anticancer (doxorubicins, daunorubicin, mitomycin, bleomycin) enzyme inhibitory (clavulanic acid) and diabetogenic (bafilomycin, streptozotocin) activities (Bérdy, 2005; Farnet and Zazopoulos, 2005). The discovery of novel bioactive 
compounds continues even in the twenty first century with the addition of new antibiotics such as daptomycin, epirubicin, carbapenem analogues, and theinamycin (Sivaramkrishna and Mahajan, 2009).

The species belong to the genus Streptomyces constitute $50 \%$ of the total population of soil actinomycetes (Vining, 1990; Bérdy, 1995). They are not only primarily soil inhabitants (Kuster, 1968), but also have been found widely distributed in a diverse range of aquatic ecosystem, including sediments obtained from deep sea (Walker and Colwell, 1975; Colquhoun et al., 1998). They were also reported to inhibit extreme environments such as cryophilic region (Moncheva et al., 2002; Raja et al., 2010) and desert soil (Diraviyam et al., 2011).

Although thousands of antibiotics have been isolated from Streptomyces, these still represent a small portion of the repertoire of bioactive compounds produced (Bérdy, 1995; Watve et al., 2001). Therefore, isolation of new Streptomyces from natural resources and characterization of their secondary metabolites is a valuable endeavor.

The current study describes the isolation as many actinomycetes strains as possible from different soil samples collected from Egypt and Libya. Also, selection of the most antibacterial active strains and optimizing the conditions for maximum yield of the bioactive materials would be performed.

\section{Materials and Methods}

\section{Soil samples collection}

Soil samples were collected from different places of Egypt and Libya including rhizosphere of some inhabitant plants (Table 1) within a period of six months (February to August 2013). Soil samples were collected from various depths of the earth surface up to 1 meter depth. They were collected in sterile small plastic tubes and properly labeled with the date and location of collection. The collected soil samples were then dried and mixed with $\mathrm{CaCO}_{3}$.

\section{Isolation and purification of actinomycetes isolates}

One $\mathrm{g}$ of each dried soil sample was suspended in $9 \mathrm{~mL}$ sterile water, and successive serial dilutions up to $10^{-4}$ were prepared. An aliquot of $0.1 \mathrm{~mL}$ of each dilution was taken and spread on $12 \mathrm{~cm}$ Petri dishes before pouring of starch-nitrate agar medium (Waksman, 1959). 1L of the medium contains 20g Starch, $2 \mathrm{~g} \mathrm{KNO}_{3}, 1 \mathrm{~g} \mathrm{~K}_{2} \mathrm{HPO}_{4}, 0.5 \mathrm{~g}$ $\mathrm{MgSO}_{4} .7 \mathrm{H}_{2} \mathrm{O}, 0.5 \mathrm{~g} \mathrm{NaCl}, 3 \mathrm{~g} \mathrm{CaCO}_{3}, 20 \mathrm{~g}$ Agar, $0.01 \mathrm{~g} \mathrm{FeSO}_{4} .7 \mathrm{H}_{2} \mathrm{O}, 1.0 \mathrm{~mL}$ trace salt solution

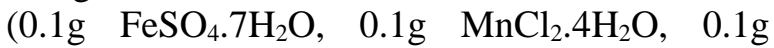
$\mathrm{ZnSO}_{4} .7 \mathrm{H}_{2} \mathrm{O}$, in $100 \mathrm{~mL}$ distilled water, $\mathrm{pH}$ was adjusted to 7.2). Plates were incubated at $30^{\circ} \mathrm{C}$ and monitored for 7 days. Growing colonies showing Streptomyces like appearance under light microscope were re-cultivated several times for purity isolation. The purified actinomycetes were preserved on Starch-nitrate agar slants at $4^{\circ} \mathrm{C}$ and in glycerol $(40 \% \mathrm{v} / \mathrm{v})$ at $-80^{\circ} \mathrm{C}$ for longer periods.

\section{Strains grouping and identification}

The color of the aerial mycelia and pigment production by the isolates were determined on Starch-nitrate agar plates after 7 days of incubation at $30^{\circ} \mathrm{C}$. The color of the substrate mycelia and those of the soluble pigment were determined for color grouping (Zhao et al., 2006). Streptomyces species isolated in this investigation were identified according to the International Streptomyces Project ISP (Shirling and Gottlieb, 1968a; 1968b; 1969; 1972; Pridham and Tresner, 1974a; 1974b; Locci, 1989).

\section{Scanning Electron Microscopy}

The spores print technique (Tresner et al., 1961) was used for electron microscopy examination. Grids with colloidal film were gently pressed over the sporulating surfaces of starch-nitrate agar. The grids were shadowed with chromium under vacuum before examination. The scanning electron microscopy (SEM, JEOL-100CX electron microscope at Alexandria University, Egypt) was carried out at $100 \mathrm{~K}$.

\section{Screening of antibacterial activities}

Antibacterial activity of the actinomycetes isolates was tested against three Gram-positive bacteria (Bacillus subtilis, Bacillus cereus and Staphylococcus aureus) and five Gram- negative bacteria (Klebsiella pneumoniae, Escherichia coli, Proteus mirabilis, Pseudomonas aeruginosa and Plant pathogenic Pseudomonas sp.). Bacterial strains (local isolates) were preserved in microbiology laboratory, Faculty of science, Damietta University, Egypt. 
The bacterial suspensions were inoculated in nutrient agar medium before solidification. Then, $1 \mathrm{~cm}$ agar disks of 7 days old culture of each actinomycetes isolate were placed over the inoculated bacterial cultures agar plates. On the other hand, $0.1 \mathrm{ml}$ of 7 days old culture metabolite (filtrated by $0.45 \mu \mathrm{m}$ Millipore filter) of each Streptomyces isolate was inoculated in $1 \mathrm{~cm}$ hole in bacterial cultures agar plates. The plates were incubated for $24 \mathrm{hrs}$ at $37^{\circ} \mathrm{C}$, and the zones of inhibition were measured.

\section{Antibacterial activity optimization}

\section{Types of media effect}

The isolated strains (16 and 36) were cultivated on eight different media in order to study their effect on the antibacterial production. These media are starch-nitrate (Waksman, 1959), starchammonium sulphate, Dox, glucose-nitrate, glycerol-nitrate, glycerol-asparagine, oatmeal, yeast-malt extract (Pridham and Lyons, 1961). After incubation, the antibacterial activity was assayed as described above.

\section{Incubation periods effect}

Selected isolates were grown in liquid starchnitrate medium, incubated at $30^{\circ} \mathrm{C}$ and at $200 \mathrm{rpm}$. After 3,5,7,9 and11 days, the crude metabolite filtrates were examined for their antibacterial activities.

\section{Initial pH effect}

The initial liquid starch-nitrate culture $\mathrm{pH}$ value was adjusted at 4.5, 5.0, 5.5, 6.0, 6.5 7.0 7.5, 8.0, $8.5,9.0,9.5$ and 10 using $1 \mathrm{~N} \mathrm{HCl}$ and $1 \mathrm{~N} \mathrm{NaOH}$. After incubation, the final $\mathrm{pH}$ was recorded and the antibacterial activities of the metabolites were determined.

\section{Temperature effect}

Inoculated starch-nitrate broth media with tested isolates were incubated at $20^{\circ} \mathrm{C}, 25^{\circ} \mathrm{C}, 30^{\circ} \mathrm{C}$ and $37^{\circ} \mathrm{C}$ respectively for 5 days at $200 \mathrm{rpm}$. The metabolite filtrates were further on used for antibacterial activity determination.

\section{Results and Discussion}

This study was performed to isolate and screen actinomycetes strains possessing antibacterial activities using different selective isolation medium followed by selection of the most antibacterial active strains for further investigation. Sixty five different actinomycetes were obtained mainly from the rhizosphere soil samples collected from different locations of Egypt and Libya (Table 1) during the year 2013. All the strains were isolated on starch-nitrate agar media which is very specific for the isolation of actinomycetes, as mostly actinomycetes are capable of degrading the polymers in this media (Demain and Davies, 1999).

All the purified isolates showed morphological characteristics of typical Streptomyces species, as their colonies possessed an earthy odor and were slow growing, aerobic, powdery, folded with aerial and substrate mycelia of different colors (Anderson and Wellington 2001). All of the isolated strains showed acid fast negative and Gram positive stain that fitted to the description of genus Streptomyces. The isolates were categorized into five color series according to their color of the mature sporulated substrate mycelium (Table 1 and Figure 1). The white series isolates were more predominant $(38.5 \%$ of the total isolates). All the isolated actinomycetes strains were screened for their antibacterial activity using agar culture disc of actinomycetes on nutrient agar medium seeded with bacteria test strains (Figure 2). Broad spectrum antibacterial activity was observed for $73.8 \%$ (48 out of 65) of the total tested isolates. Current results revealed higher frequency of antibacterial active strains than Denizci (1996) who found that $36 \%$ of screened 356 Streptomyces isolates from soils in the Aegean and East Black Sea regions of Turkey were active against tested microorganisms. The antibacterial activity of only 20 out of 150 (13.3\%) actinomycetes isolates from soil samples of west of Iran was investigated (Dehnad et al., 2010). More recently, Laidi et al., (2013) reported that nineteen out of thirty five actinomycetes isolates showed noticeable antimicrobial activities and five among the nineteen were active against both Gram positive and Gram negative bacteria, yeasts and moulds. Comparing the above mentioned results with this study, we can conclude that the Egyptian and Libyan soils are rich source of actinomycetes which are metabolically active. 
Table 1. Collection sites of soil samples and color grouping of the isolates.

\begin{tabular}{|c|c|c|c|c|c|c|c|c|c|c|c|}
\hline $\begin{array}{c}\begin{array}{c}\text { Color } \\
\text { of } \\
\text { series }\end{array} \\
\end{array}$ & $\begin{array}{l}\text { Isolate } \\
\text { number }\end{array}$ & $\begin{array}{c}\begin{array}{c}\text { Color of } \\
\text { aerial } \\
\text { mycelia }\end{array} \\
\end{array}$ & $\begin{array}{c}\text { Color of } \\
\text { substrate }\end{array}$ & Cover plant & $\begin{array}{c}\text { Site of } \\
\text { soil }\end{array}$ & \begin{tabular}{|c|}
$\begin{array}{c}\text { Color } \\
\text { of } \\
\text { series }\end{array}$ \\
\end{tabular} & $\begin{array}{l}\text { Isolate } \\
\text { number }\end{array}$ & $\begin{array}{c}\text { Color of } \\
\text { aerial } \\
\text { mycelia } \\
\end{array}$ & $\begin{array}{c}\text { Color of } \\
\text { substrate }\end{array}$ & Cover plant & $\begin{array}{c}\text { Site of } \\
\text { soil }\end{array}$ \\
\hline \multirow{25}{*}{ White } & 7 & White & N.D & Citrus aurantifolia & Damietta & \multirow{15}{*}{ Grey } & 34 & Gray & yellow & Prunus armeniaca & Tubrok \\
\hline & 9 & White & pink & Mangifera indica & Damietta & & 35 & Light gray & N.D & Psidium jugave & Benghazi \\
\hline & 11 & Pinkish white & pink & Plain soil & Damietta & & 36 & Gray & Gray & Citrus aurantium & Benghazi \\
\hline & 18 & Pinkish white & pink & Mangifera indica & Damietta & & 39 & Gray & Gray & Citrus aurantium & Benghazi \\
\hline & 21 & White & N.D & Plain soil & Damietta & & 42 & Gray & N.D & Prunus armeniaca & Tubrok \\
\hline & 22 & White & N.D & Plain soil & Damietta & & 43 & Gray & yellow & Prunus armeniaca & Tubrok \\
\hline & 23 & White & N.D & Citrus slensis & Damietta & & 44 & Gray & N.D & Punica granatuml & Tubrok \\
\hline & 24 & White & yellow & Citrus slensis & Damietta & & 45 & Gray & yellow & Prunus salicinia & Tubrok \\
\hline & 25 & White & N.D & Citrus slensis & Damietta & & 47 & Gray & N.D & Citrus slensis & Tubrok \\
\hline & 27 & White & yellow & Olea europea & Benghazi & & 49 & Gray & N.D & Punica granatuml & Tubrok \\
\hline & 30 & White & pink & Psidium jugave & Benghazi & & 50 & Gray & N.D & Olea europea & Tubrok \\
\hline & 31 & White & yellow & Morus alba & Benghazi & & 55 & Gray & N.D & Prunus arabica & Tubrok \\
\hline & 32 & White & yellow & Psidium jugave & Benghazi & & 61 & Gray & Brown & Prunus arabica & Benghazi \\
\hline & 33 & White & yellow & Prunus salicinia & Benghazi & & 63 & Gray & Gray & Morus alba & Benghazi \\
\hline & 37 & White & yellow & Prunus salicinia & Benghazi & & 64 & Gray & Gray & Prunus arabica & Benghazi \\
\hline & 38 & White & yellow & Prunus armeniaca & Benghazi & \multirow{2}{*}{ tellow } & 5 & yellow & yellow & Damietta garden & Damietta \\
\hline & 41 & White & yellow & Prunus salicinia & Tubrok & & 16 & yellow & pink & Mangifera indica & Damietta \\
\hline & 46 & White & Dark yellow & Citrus slensis & Tubrok & \multirow{13}{*}{ Red } & 2 & Pink & Dark pink & Cairo garden & Cairo \\
\hline & 48 & White & pink & Psidium jugave & Tubrok & & 8 & Pink & Pink & Mangifera indica & Damietta \\
\hline & 51 & White & N.D & Mangifera indica & Tubrok & & 12 & Pink & Dark pink & Citrus slensis & Damietta \\
\hline & 52 & White & yellow & Prunus armeniaca & Tubrok & & 14 & Pink & Pink & Mangifera indica & Damietta \\
\hline & 53 & White & Gray & Prunus salicinia & Tubrok & & 15 & Pink & Pink & Citrus slensis & Damietta \\
\hline & 54 & White & N.D & Prunus arabica & Tubrok & & 17 & Pink & Dark pink & Citrus aurantifolia & Damietta \\
\hline & 57 & White & White & Punica granatuml & Tubrok & & 19 & Pink & Pink & Mangifera indica & Damietta \\
\hline & 60 & White & yellow & Prunus arabica & Benghazi & & 20 & Pink & N.D & Citrus aurantifolia & Damietta \\
\hline \multirow{8}{*}{ Grey } & $\overline{1}$ & Gray & N.D & Citrus aurantium & Damietta & & 56 & Pink & Gray & Vitis vinifera & Tubrok \\
\hline & 3 & Gray & N.D & Cairo garden & Cairo & & 58 & Pink & Yellow & Prunus salicinia & Tubrok \\
\hline & 4 & Gray & N.D & Plain soil & Damietta & & 59 & Pink & Yellow & Prunus arabica & Tubrok \\
\hline & 6 & Gray & N.D & Plain soil & Damietta & & 62 & Pink & Brown & Prunus salicinia & Benghazi \\
\hline & 10 & Gray & N.D & Mangifera indica & Cairo & & 65 & Pink & Yellow & Vitis vinifera & Benghazi \\
\hline & 13 & Gray & N.D & Citrus aurantifoli & Damietta & \multirow[b]{2}{*}{ Violet } & 26 & Pink & Purple & Morus alba & Benghazi \\
\hline & 28 & Gray & N.D & Citrus slensis & Zleten & & 40 & Light purple & Purple & Prunus salicinia & Tubrok \\
\hline & 29 & Grayish & N.D & Olea europea & Benghazi & \multicolumn{6}{|c|}{ N.D $=$ Not Detectable } \\
\hline
\end{tabular}
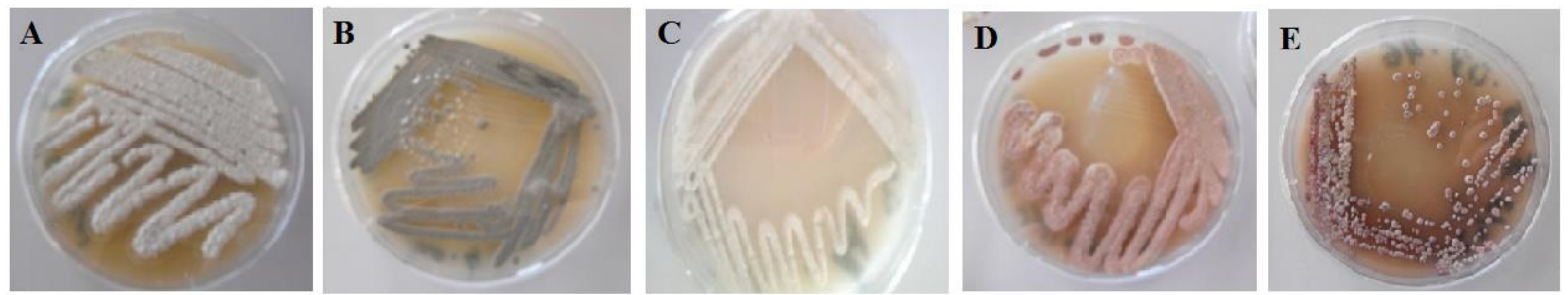

Fig 1. Representative isolates of different color series: White (A), Grey (B), Yellow (C), Red (D) and Violet (E).

The two different isolates encoded 16 and 36 showed considerable antibacterial activity towards most of the tested pathogenic bacteria than the others. They were identified as Streptomyces pluricolorescens (Egyptian isolate) and Streptomyces alni (Libyan isolate), respectively, according to their morphological and biochemical characters (Table 2 and 3). Also, their spores scanning ultrastructure were performed (Figure 3).

S. pluricolorescens was able to inhibit the growth of B. subtilis, B. cereus and S. aureus as Gram- positive bacteria and plant pathogenic Pseudomonas sp. and $P$. aeruginosa as Gramnegative bacteria. On the other hand, only $B$. subtilis, $B$. cereus, $K$. pneumoniae and Pseudomonas $s p$. were inhibited by $S$. alni. When Laidi et al., (2013) tested their isolates, they documented that $S$. labedae strain RAF-11 exhibited inhibition zone against $B$. subtilis, $M$. luteus, S. aureus, E. coli and K. pneumoniae. Also in accordance to our result, Eleven Egyptian bioactive actinomycetes isolate (El-Shobaky 2010) and other eighteen isolates (Gaber 2011) 
produced antagonistic metabolites against wide range of bacteria.

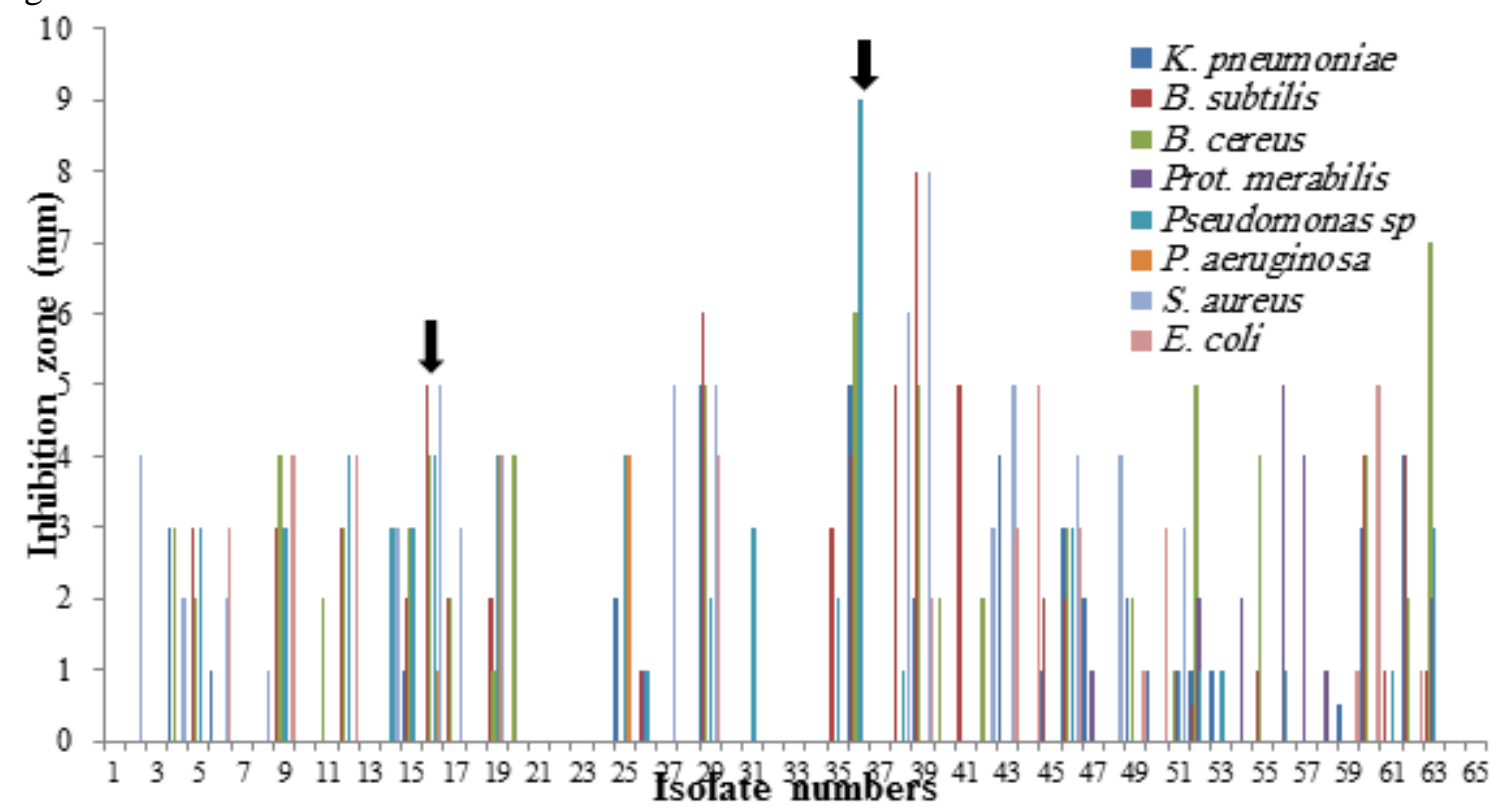

Fig 2. Antibacterial activity of the 65 actinomycetes isolates against Klebsiella pneumoniae, Bacillus subtilis, Bacillus cereus, Proteus mirablis, Plant pathogenic pseudomonas sp., Pseudomonas aeruginosa, Staphylococcus aureus, and Escherichia coli. The arrows indicated the selected isolates (16 and 36)
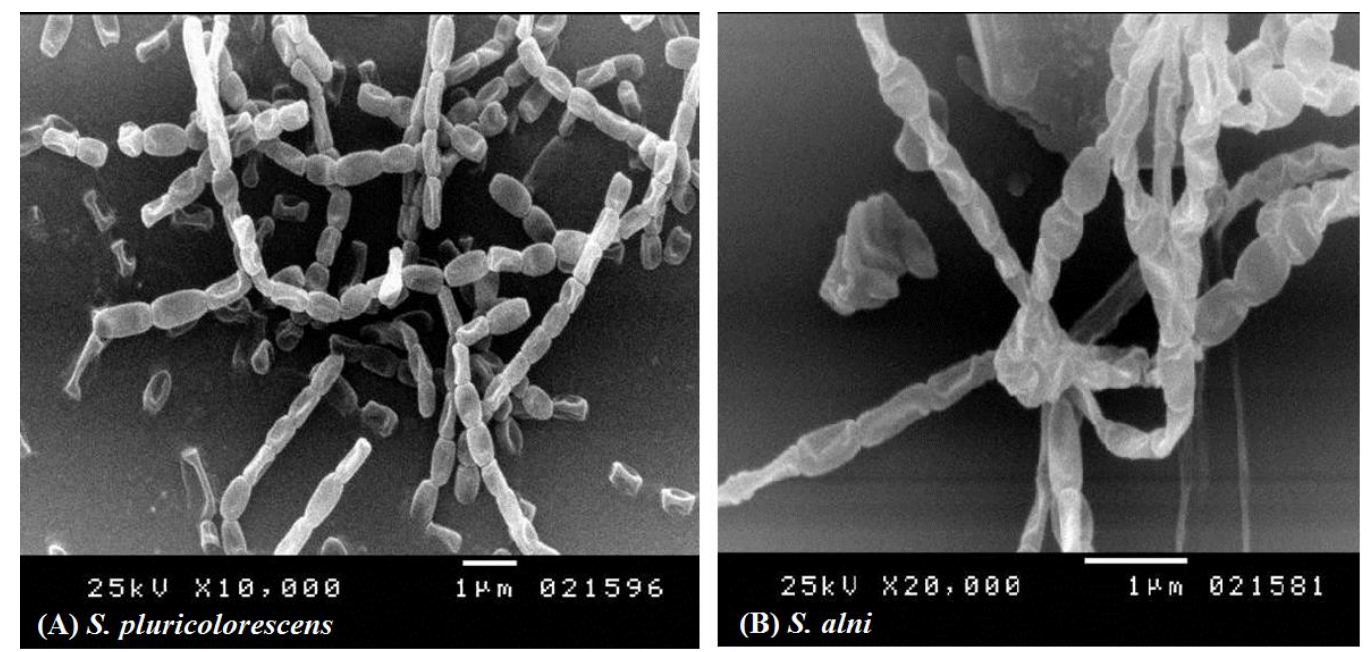

Fig 3. The scanning electron microscopy showing smooth spore surface of S. pluricolorescens (A) and S. alni (B)

Table 2. Cultural properties of seven days old cultures of S. pluricolorescens and S. alni strains on different media

\begin{tabular}{|c|c|c|c|c|c|c|c|c|c|c|}
\hline \multirow{3}{*}{$\begin{array}{l}\text { Type of } \\
\text { Medium }\end{array}$} & \multirow{2}{*}{\multicolumn{2}{|c|}{$\begin{array}{c}\text { Growth } \\
\text { appearance }\end{array}$}} & \multicolumn{6}{|c|}{ Colour Of $^{*}$} & \multirow{2}{*}{\multicolumn{2}{|c|}{$\begin{array}{l}\text { Growth } \\
\text { intensity }\end{array}$}} \\
\hline & & & \multicolumn{2}{|c|}{ Aerial mycelium } & \multicolumn{2}{|c|}{$\begin{array}{l}\text { Substrate } \\
\text { mycelium }\end{array}$} & \multicolumn{2}{|c|}{ Pigment } & & \\
\hline & $\begin{array}{c}S . \\
\text { pluricolorescens }\end{array}$ & $\begin{array}{c}S . \\
\text { alni }\end{array}$ & $\begin{array}{c}S . \\
\text { pluricolorescens }\end{array}$ & $\begin{array}{c}S . \\
\text { alni }\end{array}$ & $\begin{array}{c}S . \\
\text { pluricolorescens }\end{array}$ & $\begin{array}{c}S . \\
\text { alni }\end{array}$ & $\begin{array}{c}S . \\
\text { pluricolorescens }\end{array}$ & $\begin{array}{c}S . \\
\text { alni }\end{array}$ & $\begin{array}{c}S . \\
\text { pluricolorescens }\end{array}$ & $\begin{array}{r}S . \\
\text { alni }\end{array}$ \\
\hline $\begin{array}{l}\text { Starch } \\
\text { nitrate }\end{array}$ & Powdery & Powdery & Yellow & Grey & Pale-brown & Pale- grey & Slight brown & No pigment & ++ & ++ \\
\hline $\begin{array}{l}\text { Starch amm. } \\
\text { sulphate }\end{array}$ & Powdery & Powdery & Yellow & Grey & Pale-pink & Pale- grey & No pigment & No pigment & ++ & ++ \\
\hline Dox & Powdery & Powdery & Yellow & Grey & Pale-pink & Pale- grey & No pigment & No pigment & ++ & ++ \\
\hline $\begin{array}{l}\text { Glucose } \\
\text { nitrate }\end{array}$ & Powdery & Powdery & Yellow & Grey & Yellow & Pale- grey & No pigment & No pigment & ++ & ++ \\
\hline $\begin{array}{c}\text { Glycerol } \\
\text { nitrate }\end{array}$ & Powdery & Powdery & White & Grey & White & Pale- grey & No pigment & No pigment & + & ++ \\
\hline $\begin{array}{l}\text { Glycerol } \\
\text { aspargin }\end{array}$ & Powdery & Powdery & Yellow & Grey & White & Pale- grey & No pigment & No pigment & + & ++ \\
\hline Oatmeal & Powdery & Powdery & Page-cream & Grey & Pale-brown & Pale-grey & Slight brown & No pigment & ++ & ++ \\
\hline Yeast malt & Powdery & Waxy & Pale-pink & White & Pale-pink & White & No pigment & No pigment & \pm & ++ \\
\hline
\end{tabular}


* The colour of substrate mycelium and medium was not $\mathrm{pH}$ sensitive when treated with $0.05 \mathrm{~N} \mathrm{NaOH}$ or $0.05 \mathrm{~N} \mathrm{HCl}$. (++) good, $(+)$ moderate, $( \pm)$ poor.

Table 3. Cultural, morphological and physiological characteristics of S. pluricolorescens and S. alni

\begin{tabular}{|c|c|c|c|c|c|}
\hline Characters & & S. pluricolorescens & $\begin{array}{c}\text { S. pluricolorescens } \\
\text { type strain }\end{array}$ & S. alni & $\begin{array}{c}\text { S. alni } \\
\text { type strain }\end{array}$ \\
\hline \multirow{4}{*}{$\begin{array}{ll}\text { Colour } & \text { and } \\
\text { pigmentation } & \end{array}$} & Aerial mass color & Yellow & Yellow & Pale grey & Pale grey \\
\hline & $\begin{array}{l}\text { Melanoid pigment } \\
\text { on: } \\
\text { tyrosine, peptone } \\
\text { yeast } \\
\text { and synthetic media }\end{array}$ & - & - & 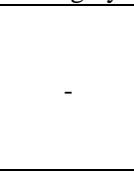 & - \\
\hline & $\begin{array}{ll}\text { Reverse } & \text { side } \\
\text { pigment } & \\
\end{array}$ & Pale reddish to yellow & Pale reddish to yellow & Grey & Grey \\
\hline & Soluble pigment & - & - & - & - \\
\hline \multirow[t]{2}{*}{ Spore morphology } & Spore chain & Straight & Rectiflexibiles & $\begin{array}{l}\text { Straight to } \\
\text { flexuous }\end{array}$ & $\begin{array}{c}\text { Straight to } \\
\text { flexuous }\end{array}$ \\
\hline & Spore surface & Smooth & Smooth & Smooth & Smooth \\
\hline \multirow{8}{*}{$\begin{array}{l}\text { Carbon } \\
\text { utilization }\end{array}$} & Arabinose & - & \pm & + & + \\
\hline & Xylose & + & + & + & + \\
\hline & Inositol & + & - & + & \pm \\
\hline & Mannitol & + & + & + & + \\
\hline & Fructose & + & + & + & + \\
\hline & Rhamnose & + & + & - & \pm \\
\hline & Sucrose & + & - & + & \pm \\
\hline & Raffinose & + & - & + & \pm \\
\hline \multirow{12}{*}{$\begin{array}{l}\text { Nitrogen } \\
\text { utilization }\end{array}$} & Potassium nitrate & ++ & nd & + & nd \\
\hline & L-valine & \pm & nd & + & nd \\
\hline & L-threonine & + & nd & - & nd \\
\hline & L-serine & + & nd & + & nd \\
\hline & L-Methionine & + & nd & - & nd \\
\hline & L-histidine & + & nd & + & nd \\
\hline & Hydroxy proline & \pm & nd & ++ & nd \\
\hline & L-proline & ++ & nd & ++ & nd \\
\hline & L-Tyrosine & + & nd & - & nd \\
\hline & Casein & + & nd & - & nd \\
\hline & Peptone & ++ & nd & ++ & nd \\
\hline & Arginine & + & & + & \\
\hline \multirow{8}{*}{$\begin{array}{l}\text { Physiological } \\
\text { properties }\end{array}$} & Milk coagulation & \pm & $\overline{\mathrm{nd}}$ & + & nd \\
\hline & Milk peptonization & \pm & nd & + & nd \\
\hline & Starch hydrolysis & + & nd & + & nd \\
\hline & Urea hydrolysis & + & nd & + & nd \\
\hline & Gelatin liquefaction & + & nd & + & nd \\
\hline & Melanin/L-tyrosine & - & nd & - & nd \\
\hline & $\begin{array}{l}\text { Cellulose } \\
\text { degradation }\end{array}$ & - & nd & - & nd \\
\hline & Esculin degradation & + & nd & + & nd \\
\hline
\end{tabular}

$(++)$ good, (+) moderate, $( \pm)$ poor, $(-)$ nil, $($ nd) not detected

The optimum condition for growing the two isolates was studied. The temperature range for growing was $30^{\circ} \mathrm{C}$ to $37^{\circ} \mathrm{C}$ for $S$. pluricolorescens (Figure 4), while $S$. alni was able to grow at $20^{\circ} \mathrm{C}$ to $40^{\circ} \mathrm{C}$ (Figure 5). The growth of both species was not detected below or above those temperatures when tested on starch nitrate medium. The difference in their mesophilic character might be attributed to the effect of geographic area of isolation site, as $S$. alni was isolated from Benghazi (Libya) which possesses climatic characters different from Damietta (Egypt) for S. pluricolorescens. The optimum conditions for maximum antibacterial production were observed at $30^{\circ} \mathrm{C}$ of temperature, $\mathrm{pH} 7$ and maximum period of culturing reached 5 days for both $S$. pluricolorescens and S. alni (data not shown). Hassan et al., (2001) studied the effect of temperature on the antimicrobial productivity produced by $S$. violatus and they found that increasing the incubation temperature from $20^{\circ} \mathrm{C}$ to $30^{\circ} \mathrm{C}$ led to increase growth and productivity of the antibiotic, while raising the temperature higher than $35^{\circ} \mathrm{C}$ has had an adverse effect on growth and productivity. Maximum yield of the active metabolite produced by $S$. pluricolorescens and $S$. 
alni was obtained at of $30^{\circ} \mathrm{C}$ which is quite similar to some other mesophilic Streptomyces species and isolates (Gubte and Kulkarni, 2002; AlKhaldi, 2003; Kiviharju et al., 2004; Atta et al., 2011; Vijayakumar et al., 2012; Ababutain et al., 2013; Bhavana et al., 2014). Also, other study by Padma et al., (2002) and Jain et al., (2011) recorded that the best incubation temperature was $29^{\circ} \mathrm{C}$ and $28^{\circ} \mathrm{C}$ respectively. Some actinomycetes strains might need higher temperature up to $35^{\circ} \mathrm{C}$ to get the maximum antibiotic production as in case of $S$. albidoflavus (Narayana and Vijayalakshmi 2008).

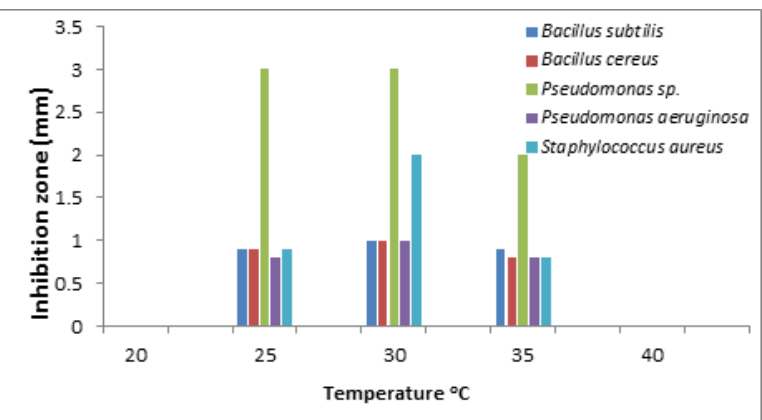

Fig 4. Effect of temperature ${ }^{\circ} \mathrm{C}$ on the antibacterial activity of $S$. pluricolorescens against different bacterial strains using $100 \mu \mathrm{l}$ filtrate of $S$. pluricolorescens culture.

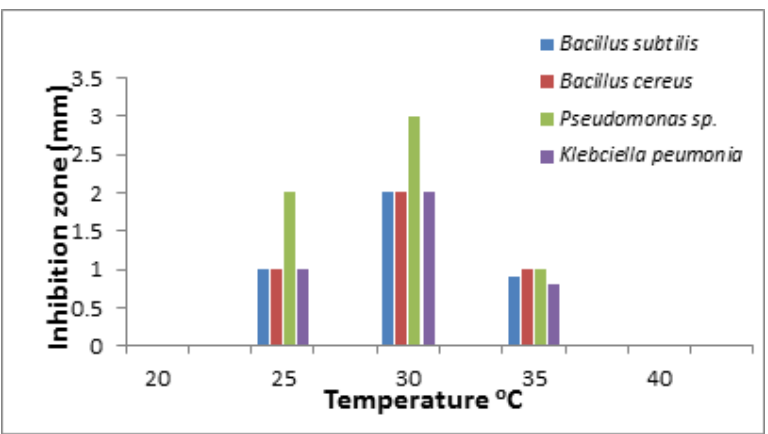

Fig 5. Effect of temperature ${ }^{\circ} \mathrm{C}$ on the antibacterial activity of $S$. alni against different bacterial strains using $100 \mu$ l filtrate of $S$. alni culture.

Maximum antibacterial activity was obtained in case of both tested strains at an initial $\mathrm{pH} 7$ (Figures 6 and 7). Chattopadhyay and Sen (1997) noted that $\mathrm{pH} 7$ is the most appropriate $\mathrm{pH}$ values to produce the highest amount of antibiotic of different types of Streptomyces. This is also in agreement with Narayana and Vijayalakshmi (2008); Atta et al., (2011) and Vijayakumar et al., (2012). Furthermore, It was found that the highest amount of productivity of antibiotic by $S$. violatus and $S$. carpaticus was at $\mathrm{pH} 7.5$ and 7.2 respectively (El-Naggar et al., 2003; Bhavana et al., 2014). Also other studies by Crawford et al.,
(1993) and Vijayakumar et al., (2012) recorded that the best growth of actinomycetes strains were between $\mathrm{pH}$ 6.5-8 and few could not grow at $\mathrm{pH}$ 6.0 , nevertheless the failure of a large number of actinomycetes to grow at $\mathrm{pH} 5.5$. On the contrary, Holtzel et al., (1998) and Ababutain et al., (2013) reported the highest antibiotic production at $\mathrm{pH}$ 5.5 and 6 respectively.

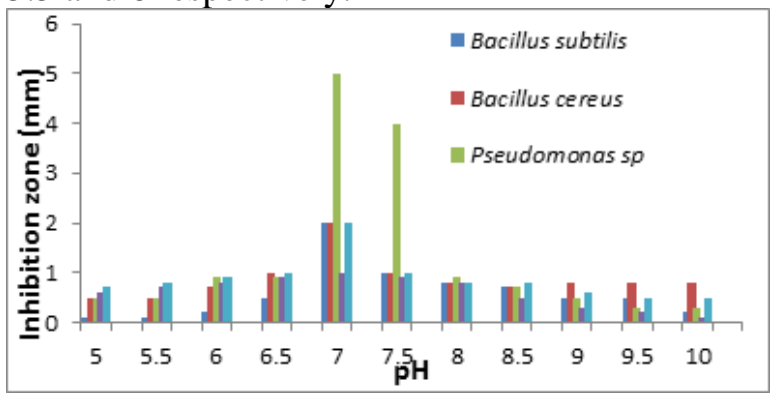

Fig 6. Effect of $\mathrm{pH}$ on the antibacterial activity of $S$. pluricolorescens against different bacterial strains using $100 \mu \mathrm{l}$ filtrate of $S$. pluricolorescens culture.

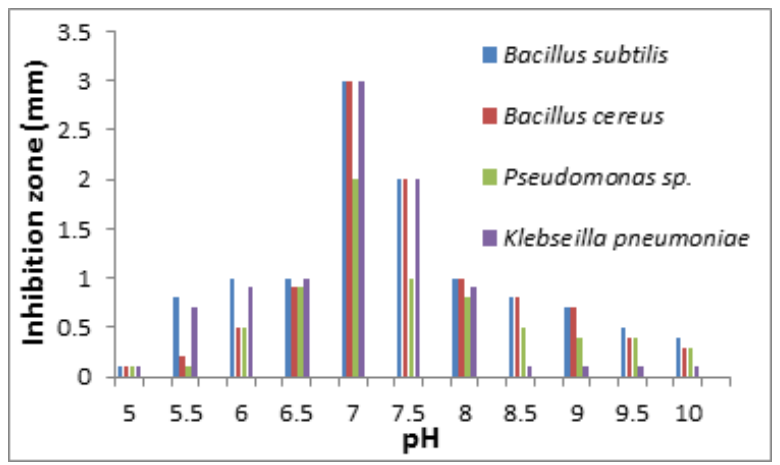

Fig 7. Effect of $\mathrm{pH}$ on the antibacterial activity of $S$. alni against different bacterial strains using $100 \mu \mathrm{l}$ filtrate of $S$. alni culture.

Maximum growth and biosynthesis occurred at the end of an incubation period of five days on Starch nitrate medium for both studied strains (Figures 8 and 9). Five days incubation period was found to be the best by many researchers (Ryoo et al., 1997; Holtzel et al., 1998; Narayana and Vijayalakshmi 2008; Vijayakumar et al., 2012; Bhavana et al., 2014). In addition, the highest productivity after four days of incubation was also recorded (ElNaggar et al., 2003; Atta et al., 2011; Song et al., 2012). Some Streptomyses species needed more incubation period for maximum bioactive compounds production reached up to seven days (Hassan et al., 2001; Venkateswarlu et al., 2004; Al-Zahrani 2007; Ababutain et al., 2013) and even ten days (Jain et al., 2011).

The best production of antibacterial compounds for $S$. pluricolorescens and S. alni was optimized on eight different types of media. Both agar discs and Millipore-sterile filtrates of each solid and 
culture growth medium, respectively, were tested against bacteria (Figures 10 and 11). The results showed that the most suitable media for $S$. pluricolorescens antibacterial activity were Dox (containing sucrose and sodium nitrate) and starch ammonium sulfate media followed by starch nitrate medium, while starch-nitrate medium exhibited the maximum antibacterial activity for S. alni. In general, many researchers found that starch nitrate medium is suitable for best productivity (Gaber 2011; Vijayakumar et al., 2012; Ababutain et al., 2013), as the soluble starch is considered best carbon source for the highest productivity of the bioactive substances (Atta $e t$ al., 2011; Vijayakumar et al., 2012). Different carbon sources could influence the maximum productivity depending on the Streptomyces species. For example, glycerol was the most suitable carbon source for $S$. antibioticus productivity (Haque et al., 1995), and maltose for $S$. albidoflavus. Sometime, as in the case of Actinomycetes YJ1 strain; a mixture of two carbon sources like sucrose and soluble starch is most appropriate (Song et al., 2012).

Regarding to the nitrogen sources, it was found that sodium nitrate (Aman 2001; El-Naggar 2003), in addition, potassium nitrate (Atta et al., 2011) were the most appropriate source of nitrogen for best productivity. Sometime ammonium as succinate salt possessed a good productivity (Gesheva et al., (2004). Venkateswarlu et al., (2004) recorded that the rifamycin productivity was increased to the maximum when ammonium sulphate, soybean and peanuts were used. Amino acids such as lysine also increased the production

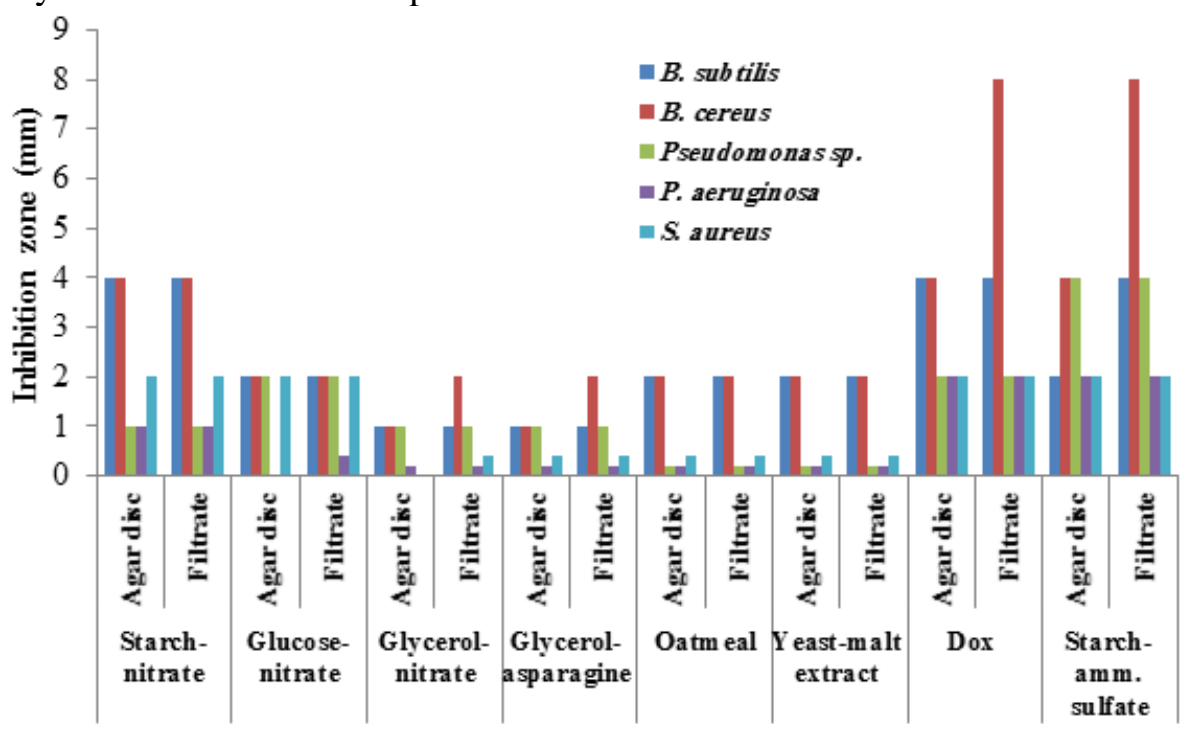

Fig 10. Effect of the type of media on the antibacterial activity of S. pluricolorescens against different bacterial strains using $1 \mathrm{~cm}$ agar disc and $100 \mu \mathrm{l}$ filtrate of S. pluricolorescens culture. of antibiotic extracted from $S$. antibioticus (Theobald et al., 2000).

Further investigations should be carried out in order to separate and identify probably novel antibiotic active compounds from these promising Streptomyces isolates.

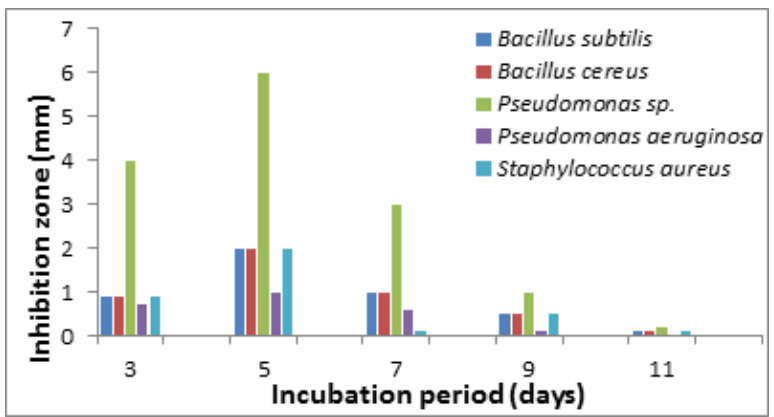

Fig 8. Effect of incubation period on the antibacterial activity of $S$. pluricolorescens against different bacterial strains using $100 \mu \mathrm{l}$ filtrate of $S$. pluricolorescens culture.

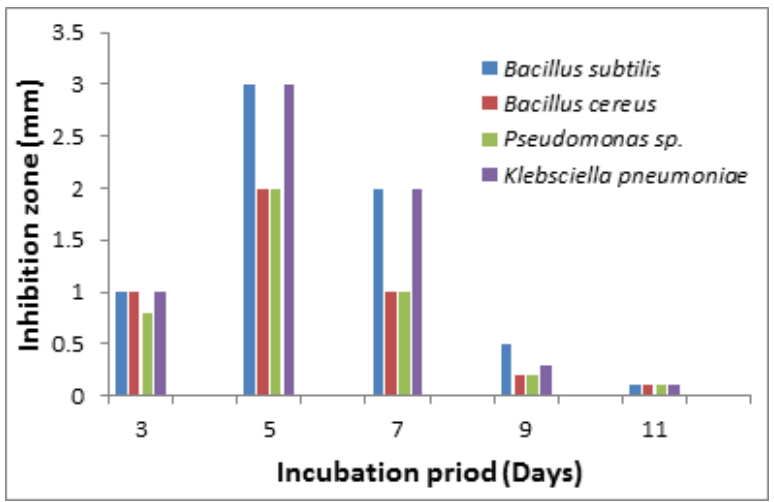

Fig 9. Effect of incubation period on the antibacterial activity of $S$. alni against different bacterial strains using $100 \mu$ l filtrate of $S$. alni culture. 


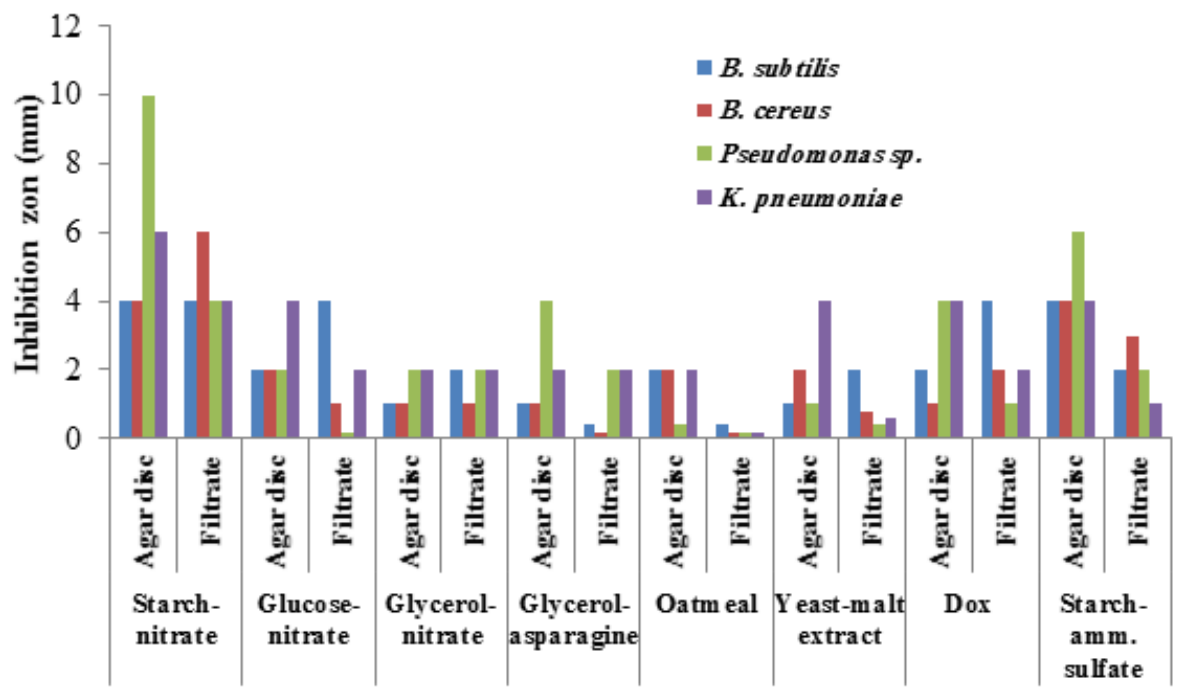

Fig 11. Effect of the type of media on the antibacterial activity of S. alni against different bacterial strains using $1 \mathrm{~cm}$ agar disc and $100 \mu \mathrm{l}$ filtrate of $S$. alni culture.

\section{Acknowledgment}

Nouria S El-Manafi was supported by a Libyan Government Scholarship at Botany Department, Faculty of Science, Damietta University.

\section{References}

Ababutain IM, Abdul-Aziz ZK, AL-Meshhen NA (2013) Optimization of environmental and nutritional conditions to improve growth and antibiotic productions by Streptomyces sp. isolated from Saudi Arabia Soil. International Research Journal of Microbiology (IRJM) 4(8): 179-187

Al-Khaldi EMUA (2003) Microbiological studies on some Streptomycetes isolated from the soil of the eastern province of the kingdom of Saudi Arabia. MSc Thesis, Botany and Microbiology Department, Girls Science College, Dammam, Kingdom of Saudi Arabia

Al-Zahrani S, (2007) Studies on the antimicrobial activity of Streptomyces sp. isolated from Jazan. J. Kau. Sci., 19:1-186

Aman GZ, (2001) Studies on some actinomycete isolates from certain desert soil samples. $\mathrm{PhD}$ Thesis, Faculty of Science, Al-Azhar University, Egypt

Anderson AS, Wellington MHE (2001) The taxonomy of Streptomyces and related genera. Int. J. of Syst. Evol. Microbiol. 51: 797-814.

Atta HM, El-Sayed AS, El-Desoukey MA, Hassan MM, El-Gazar MM, (2011) Screening, identification, phylogenetic characterization and optimization of antimicrobial agents biosynthesis produced by Streptomyces rimosus. World Rural Observations, 3(3):40-52.

Bérdy J, (1995) Are Actinomycetes exhausted as a source of secondary metabolites in Proceedings of the 9th Symposium Actinomycetes, 13-34.

Bérdy J, (2005) Bioactive microbial metabolites: a personal view. Journal of Antibiotics, 58:1-26.

Bhavana H, Talluri VP, Kumar KS, Rajagopal SV, (2014) Optimization of culture conditions of Streptomyces carpaticus (MTCC-11062) for the production of antimicrobial compound. International Journal of Pharmacy and Pharmaceutical Sciences, 6(8): 281-285

Cassell GH, Mekalanos J, (2001) Development of antimicrobial agents in the era of new and reemerging infectious diseases and increasing antibiotic resistance. JAMA. 285:601-605.

Chattopadhyay D, Sen SK, (1997) Optimization of cultural conditions for antifungal antibiotic accumulation by Streptomyces rochei G164. Hindustan. Antibiot. Bull., 39 (1-4): 64-71.

Colquhoun JA, Mexson J, Goodfellow M, Ward AC, Horikoshi K, Bull AT, (1998) Novel rhodococci and other mycolate actinomycetes from the deep sea. Antonie van Leeuwenhoek, 74:27-40.

Crawford DL, Lynch JM, Whipps JM, Ousley MA, (1993) Isolation and characterization of actinomycete antagonists of a fungi root pathogen. Applied and Environmental Microbiology, 59(11):3899-3905.

Dehnad A, Parsa L, Bakhshi R, Soofiani SA, Mokhtarzadeh A, (2010) Investigation antibacterial activity of streptomycetes isolates from soil samples, West of Iran. African Journal of Microbiology Research, 4:1542-1549.

Demain AL, Davies JE, (1999) Manual of industrial microbiology and biotechnology, Chapter 1, 
American Society for Microbiology, Washington, DC, USA, 2nd edition.

Denizci AA, (1996) Ege ve DoÛu Karadeniz b.lgesi topraklarinden izole edilen aktinomisetlerden antibakteriyal antibiyotiklerin aranmasÝ ve.retimi. zerine bir araßtÝrma. Doctoral thesis, Ege. niversitesi, Fen Bilimleri Enstit.s.

Diraviyam T, Radhakrishnan M, Balagurunathan R, (2011) Antioxidant activity of melanin pigment from Streptomyces species D5 isolated from Desert soil, Rajasthan, India. Drug Invention Today, 3:123.

El-Naggar MY, Hassan MA, Said WY, El-Aassar SA, (2003). Effect of support materials on antibiotic MSW2000 production by immobilized Streptomyces violatus. J. Gen. Appl. Microbiol., 49 (4):235-243

El-Shobaky AMI, (2010) Biotechnological and molecular biologic studies on the production of antibiotics from actinobacteria. $\mathrm{PhD}$ Thesis, Faculty of Science, Mansoura University, Egypt.

Farnet CM, Zazopoulos E, (2005) Improving drug discovery form microorganisms. In: Natural products: Drug discovery and Therapeutic medicine. Zhang L, Demain AL, Editors. Totowa: Humana press Inc, p. 95.

Gaber BT, (2011) Studies on the antimicrobial activities of some bacteria belonging to actinomycetes. MSc Thesis, Faculty of Science, Damietta Branch, Mansoura University, Egypt.

Gesheva V, Ivanova V, Gesheva R, (2004) Effects of nutrients on the production of AK-111-81 macrolide antibiotic by Streptomyces hygroscopicus. Microbiological., 160(3):243-248.

Gubte MD, Kulkarni PR, (2002) A study of antifungal antibiotic production by Streptomyces chattanoogensis MTCC3423 using full factorial design. Literature Appl. Microbiology, 35(7): 6-22.

Haque SF, Sen SK, Pal SC, (1995) Nutrient optimization for production of broad spectrum antibiotic by Streptomyces antiboticus SRI5- 4 . Acta. Microbiol. Immunol. Hung., 42 (2):155-162.

Hassan M, El-Naggar M, Said W, (2001) Physiological factors affecting the production of an antimicrobial substance by Streptomyces violatus in batch culture. Egyptian J. of Biology, 3:1-10.

Holtzel A, Kempter C, Metzger JM, Jung G, Groth I, Fritz T, Fiedler HP, (1998) Spirofungin, a new antifungal. J. Antibiot., 51(8):699-707.

Jain R, Zaidi KU, Parveen N, Saxena A, (2011) Optimization of Cultural Conditions for the Production of Antibiotic by Streptomyces sp. VRY1. Recent Research in Science and Technology, 3(10):81-87

Kiviharju K, Leisola M, Eerikainen T, (2004) Optimization of Streptomyces peucetius var. caesius N47 cultivation and erhodomycinone - production using experimental designs and response surface methods. J. Industrial Microbiol. Biotechnol., 31(10):475-481.

Kuster E, (1968). Taxonomy of soil actinomycetes and related organisms. In: Ecology of soil bacteria. Gray $\mathrm{S}$, Parkinson T, Editors, Liverpool, Liverpool University Press.

Laidi RF, Abderrahman A, Hocine Norya AA (2013) Identification and antibiosis of a novel actinomycetes strain RAF-11 isolated from Iraqi soil. International Journal of Sciences: Basic and Applied Research (IJSBAR) 12: 141-159.

Locci R (1989) Genus Streptomyces and related genera. In: Williams ST, Sharpe ME, Holt JG (eds.). Bergey's Manual of Determinative Bacteriology (vol. 4), The Williams and Wilkins Co., Baltimore, p. 2451-2508.

Moncheva P, Tishkov S, Dimitrova N, Chipeva V, Bogatzevska N, (2002) Characteristics of soil actinomycetes from Antartica. J. Cult. Coll., 3:3-14.

Narayana KJP and Vijayalakshmi M, (2008) Optimization of antimicrobial metabolites production by Streptomyces albidoflavus. Research Journal of Pharmacology, 2(1):4-7

Padma PN, Rao AB, Yadav JS, Reddy G, (2002). Optimization of fermentation conditions for production of glycopeptide antibiotic vancomycin by Amcolatopsis orientalis. Appl. Biochem. Biotechnol., 102-103(1-6): 395-405.

Pridham TG, Lyons J (1961) Streptomyces albus (Rossi-Doria) Waksman et Henrici: Taxonomic study of strains labeled S. albus. J. Bacteriol. 81(3): 431-441.

Pridham TG, Tresner HD (1974a). Family Streptomycetaceae Waksman and Henrici. pp.747748. In: R.E. Buchanan and N.E. Gibbons (eds.), Bergey's manual of determinative bacteriology. 8th ed. The Williams and Wilkins Co., Baltimore.

Pridham TG, Tresner HD, (1974b). Genus I. Streptomyces Waksman and Henrici. pp.748-829. In: R.E. Buchanan and N.E. Gibbons (eds.), Bergey's manual of determinative bacteriology. 8th ed. The Williams and Wilkins Co., Baltimore.

Raja A, Prabakaran P, Gajalakshmi P, Rahman AH, (2010). A population study of psychrophilic actinomycetes isolated from Rothang Hill-Manali soil sample. J. Pure Applied Microbiol., 4:847-851.

Ryoo IJ, Song KS, Kim JP, Kim WG, Koshina H, Yoo ID, (1997) A new cytotoxic phenylthial-iazoline, 4methylaeruginoic acid from Streptomyces sp. KCT9303. J. Antibiot., 50(3):256-258.

Shirling EB, Gottlieb D, (1968a) Cooperative description of type cultures of Streptomyces. II. Species descriptions from the first study. Int. J. Syst. Bacteriol. 18:69-189.

Shirling EB, Gottlieb D, (1968b) Cooperative description of type cultures of Streptomyces III. 
Additional species description from first and second studies. Int. J. Syst. Bacteriol. 18:279-392.

Shirling EB, Gottlieb D, (1969) Cooperative description of type cultures of Streptomyces. IV. Species description from the second, third and fourth studies. Int. J. Syst. Bacteriol. 19:391-512.

Shirling EB, Gottlieb D, (1972) Cooperative description of type strains of Streptomyces. V. Additional descriptions. Int. J. Syst. Bacteriol. 22:265-394.

Sivaramkrishna H, Mahajan G, (2009) Microbes an eternal source of innovative drugs. Express Pharma, 16-30.

Song Q, Huang Y, Yang H, (2012) Optimization of fermentation conditions for antibiotic production by Actinomycetes YJ1 strain against Sclerotinia sclerotiorum. Journal of Agricultural Science, 4(7):95-102

Theobald U, Schimana J, Fiedler HP, (2000) Microbial growth and production kinetics of Streptomyces antibioticus Tu 6040. Antonie. Van. Leeuwenhoek, 78(3-4):307-313

Tresner HD, Davies MC, Backus EJ, (1961) Electron microscopy studies of Streptomyces spore morphology and its role in species differentiation. $\mathrm{J}$. Bacteriol. 81:70-80.

Venkateswarlu G, Murali Krishna PS, Venkateswar Rao L, (2004) Production of rifamycin using Amycolatopsis mediterranei (MTCC14).
Bioprocess and Biosystems Engineering, 20(1): 2730.

Vijayakumar R, Panneerselvam K, Muthukumar C. Thajuddin N, Panneerselvam A, Saravanamuthu R, (2012) Optimization of antimicrobial production by a marine actinomycete Streptomyces afghaniensis VPTS3-1 isolated from Palk Strait, east coast of India. Indian J Microbiol., 52(2):230-239

Vining LC, (1990) Functions of secondary metabolites. Annual Review of Microbiology, 44:395-427.

Waksman SA (1959) Strain specificity and production of antibiotic substances. Characterization and classification of species within the Streptomyces griseus group. Proc. Natl. Acad. Sci. USA 45: 10431047.

Walker D, Colwell RR, (1975) Factors affecting enumeration and isolation of actinomycetes from Chesapeake Bay and South eastern Atlantic Ocean sediments. Mar. Biol. 30:193-201.

Watve MG, Tickoo R, Jog MM, Bhole BD, (2001) How many antibiotics are produced by the genus Streptomyces? Archives of Microbiology, 176:386-390.

Zhao H, Parry RL, Ellis DI, Griffith GW, Goodacre R, (2006) The rapid differentiation of Streptomyces isolates using fourier transform infrared spectroscopy. Vibrational Spectroscopy, 40: 213218.

\section{عنوان البحث: النشاط ضد بكتيري لنوعين من جنس إستربتوميسيس معزولتين من تربتين مصرية وليبية أحمد قاسم عبد الصمد السيد'، محمد إسماعيل أبودبارة'، نورية صالح المنفيخ ' ق قسم النبات ـ كلية العلوم - جامعة دمياط - دمياط ـ مصر

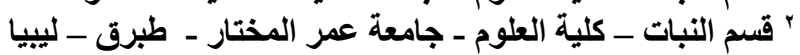

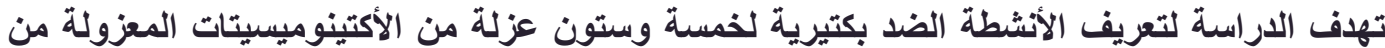

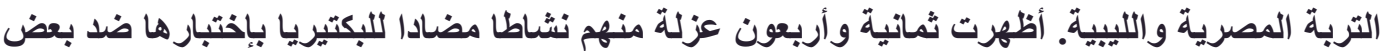

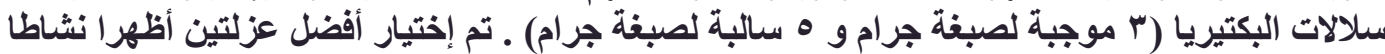

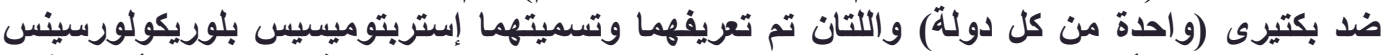

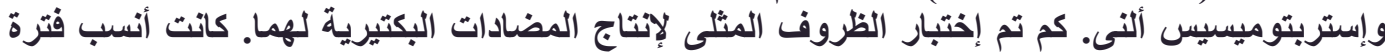

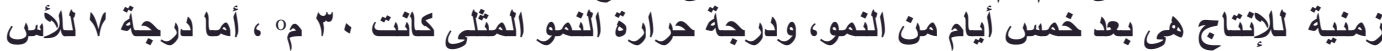

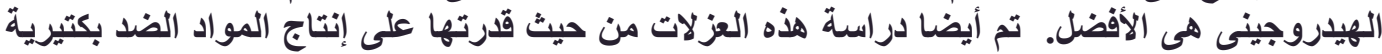

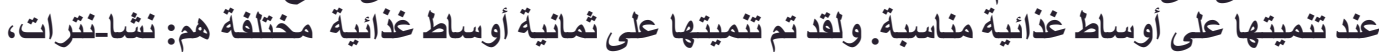

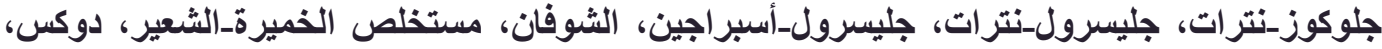

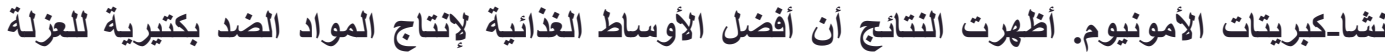

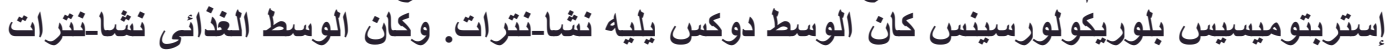
الأفضل في حالة العزلة إستربتوميسيسيس ألنى.
} 